\title{
Manajemen Logistik Perencanaan dan Pendistribusian Obat pada Intalasi Farmasi di RSUP Dr M. Djamil Padang
}

\section{Dicho Zhuhriano Yasli}

Program Studi S1 Administrasi Rumah Sakit, STIKes Dharma Landbouw Padang; dichozhuhriano@gmail.com (koresponden)

Rahmadhani

Program Studi D3 Rekam Medis dan Informasi Kesehatan, STIKes Dharma Landbouw Padang; rahmadhani17387@gmail.com

Yulfa Yulia

Program Studi D3 Rekam Medis dan Informasi Kesehatan, STIKes Dharma Landbouw Padang; yulfayuliayy@gmail.com

\begin{abstract}
Logistic management and the need for medicines in a hospital can be implemented when medicine management is organized effectively and efficiently by conducting general standard of planning and distribution. The objective of the research was to find out and to analyze the process of medicine planning and medicine distribution in the process of medicine logistic management in the Pharmaceutical Installation of Dr M. Djamil General Hospital, Padang. The research used qualitative interactive method by using 7 sources of information taken by using purposive. Resources in research was the General Director and Human Resources, Head of Pharmacy, Parts Logistics, Procurement Section, Receipt of Goods, Pharmacists and Doctorsin. The results showed the Drug logistics management in Hospital Pharmacy Dr M. Djamil: a) Planning Drugs in good value and have followed the procedure of Dr M. Djamil General Hospital, Padang, b) Distribution of Drugs in value it her because it in volves external parties in meeting the needs of medicineat the hospital pharmacy of Dr M. Djamil General Hospital Padang.

Keywords: hospital logistic management; logistic management in pharmacy installation
\end{abstract}

\begin{abstract}
ABSTRAK
Manajemen logistik obat yang baik melalui pengelolaan, perencanaan dan pendistribusian merupakan pegangan umum untuk dapat terselenggaranya pengelolaan obat yang efektif dan efisien serta dapat memenuhi kebutuhan obat di rumah sakit. Tujuan penelitian ini untuk mengetahui dan menganalisis proses perencanaan obat dan menganalisis proses pendistribusian obat yang ada di dalam proses manajemen logistik obat di Instalasi Farmasi Rumah Sakit Umum Dr M. Djamil Kota Padang. Metode penelitian ini adalah kualitatif interaktif penentuan sumber informasi melibatkan 7 sumber informasi dengan mengunakan teknik purposive. Sumber informasi pada penelitian adalah Direktur Umum dan SDM, Kepala Instalasi Farmasi, Bagian Logistik, Bagian Pengadaan Barang, SUB Penerimaan Barang, Apoteker dan Dokter Umum Rumah Sakit. Hasil penelitian menunjukkan proses manajemen logistik obat di Instalasi Farmasi Rumah Sakit Dr M. Djamil adalah sebagai berikut, a) Perencanaan Obat di nilai baik dan sudah mengikuti prosedur, b) Pendistribusian Obat di nilai belum baik karena melibatkan pihak ekternal dalam memenuhi kebutuhan obat apotik di Rumah Sakit Dr. M. Djamil Kota Padang.
\end{abstract}

Kata kunci: manajemen logistik rumah sakit; manajemen logistik di instalasi farmasi

\section{PENDAHULUAN}

Rumah Sakit mengunakan pembekalan farmasi (obat-obatan, bahan kimia, bahan radiologi, bahan alat kesehatan, alat kedokteran dan gas medik) dan 50\% dari seluruh pemasukan rumah sakit berasal dari pengelolaan pembekalan farmasi ${ }^{(1)}{ }^{(2)}$.

Menurut Syafirdi (2014) melalui media elektronik merdeka.com, salah seorang warga Kota Padang yang menderita gagal ginjal melaporkan pihak rumah sakit umum Dr. M. Djamil Kota Padang ke Ombudsman karena rumah sakit umum Dr. M. Djamil telat memberika obat cuci darah kepadanya, keterlambatan tersebut terjadi setiap bulannya tiga sampai empat hari obat yang diminta baru didapat.

Menurut Ayu (2015) melalui harian padang expres menyebutkan bahwa, ruangan tunggu rumah sakit Dr. M. Djamil Kota Padang terlihat dipadati pengunjung yang akan berobat. Selain itu pengunjung juga tampak gelisah karena kelamaan menunggu antrian panjang untuk mengambil obat. Hasil wawancara wartawan Padang Expres kepada salah satu keluarga pasien, kedatangannya di rumah sakit Dr. M. Djamil mengantarkan orang 
tuanya berobat yang merupakan pasien rujukan dari rumah sakit Padang Panjang, biaya rumah sakit orang tuanya ditanggung oleh BPJS tetapi ada beberapa obat yang harus dibeli diluar karena obat tidak ada di rumah sakit $^{(3)}$

Hasil studi pendahuluan yang peneliti lakukan di rumah sakit umum Dr. M. Djamil Kota Padang diperoleh informasi bahwa banyaknya pasien yang menunggu antrian obat dari apotik yang ada di rumah sakit. Peneliti juga melakukan wawancara dengan 10 orang pasien rawat jalan yang menunggu antrian obat di apotik rumah sakit mengatakan bahwa, $7(70 \%)$ pasien merasa tidak puas dengan lamanya menunggu antrian obat di ruang tunggu apotik dan obat yang diminta juga belum tentu ada dari pada lama menunggu lebih baik membeli obat di apotik luar rumah sakit, $3(30 \%)$ pasien yang menunggu obat berpendapat proses menunggu obatnya memang lama \pm 60 menit waktu menunggu obat, dari pada mengeluarkan biaya lagi untuk membeli obat di apotik luar lebih baik menunggu, walaupun obat yang di minta juga belum tentu ada. Ketersediaan obat sesuai dengan kebutuhan pelayanan kesehatan dasar di Kota Padang mencapai 86,2\% (Profil Kesehatan Kabupaten/Kota, 2014), bila dibandingkan dengan standar pelayanan minimal rumah sakit secara Nasional yaitu 100\%, maka Kota Padang masih dibawah target tersebut. Berdasarkan masalah ini dapat diasumsikan pelaksanaan manajemen logistik obat di instalasi farmasi rumah sakit menemui kendala dalam proses perencanaan dan pendistribusian obat ${ }^{(4)}$.

Berdasarkan permasalahan penelitian, maka dapat dirumusankan tujuan penelitian yaitu menganalisis proses perencanaan obat dan proses pendistribusian obat yang terlibat didalam proses manajemen logistik obat di instalasi farmasi rumah sakit.

Berdasarkan permasalahan penelitian, maka dapat dirumusankan tujuan penelitian sebagi berikut:

1. Menganalisis proses perencanaan obat di instalasi farmasi rumah sakit.

2. Menganalisis proses pendistribusian obat di instalasi farmasi rumah sakit.

\section{METODE}

Penelitian ini menggunakan metode penelitian kualitatif interaktif karena peneliti ingin menginterprestasikan berbagai fenomena terkait dengan pelaksananan manajemen logistik obat di instalasi farmasi rumah sakit. Peneliti menginterprestasikan fenomena-fenomena bagaimana orang-orang mencari makna dari fenomena-fenomena tersebut ${ }^{(5)}$.

Penelitian dilakukan di rumah sakit umum Dr. M. Djamil Kota Padang karena pelaksanaan manajemen logistik obat di instalasi farmasi diasumsikan belum terlaksana dengan baik dan belum mampu melayani kebutuhan obat pasien yang berobat di rumah sakit.

Penelitian ini direncanakan selama 8 bulan yaitu dimulai penyusunan proposal pada bulan Februari 2019 sampai bulan September 2019. Perencanaan penelitian dimulai dari persetujuan judul penelitian, survei pendahuluan, tinjauan pustaka, penelitian lapangan dan menganalisis data yang telah diperoleh selama pengumpulan data.

sumber informasi pada penelitian ini mengunakan metode purposive. Selama pengumpulan data ini yang menjadi sumber informasi berjumlah tujuh orang yaitu Direktur Umum dan SDM, Kepala Instalasi Farmasi, Staf Bagian Logistik, Staf Bagian Pengadaan, Sub PJ Penerimaan Barang, Apoteker Rumah Sakit, dan salah satu dokter umum di Rumah Sakit Umum Dr. M. Djamil Kota Padang adalah sebagaimana pada tabel 1.

Tabel 1. Karakteristik Sumber Informasi

\begin{tabular}{|l|l|c|c|c|}
\hline No & \multicolumn{1}{|c|}{ Jabatan } & Umur & Jenis kelamin & Pendidikan \\
\hline 1 & Direktur Umum dan SDM & 54 & Lk & S-2 \\
2 & Ka. Instalasi Farmasi & 49 & Pr & S-1 \\
3 & Bagian Logistik Rumah Sakit & 48 & Lk & S-1 \\
4 & Bagian Pengadaan Barang & 48 & Lk & S-1 \\
5 & SUB. PJ. Penerimaan Barang & 39 & Pr & S- 1 \\
6 & Apoteker Rumah Sakit & 40 & Pr & S-1 \\
7 & Dokter Umum & 35 & Lk & S-1 \\
\hline
\end{tabular}

\section{HASIL}

Pengumpulan data tentang variable manajemen logistik di Rumah Sakit Dr M. Djamil Kota Padang meliputi beberapa subvaiabel yaitu perencanaan obat, pengadaan obat, penyimpanan obat, pendistribusian obat, 
penghapusan obat dan sumber daya manusia di instalasi farmasi. Sebagaimana hasil penelitian yang peneliti uraikan berikut ini.

\section{Perencanaan Obat di Instalasi Farmasi Rumah Sakit Umum Dr M. Djamil Kota Padang}

Hasil wawancara kepada sumber informasi, perencanaan obat di Instalasi Farmasi sebagai berikut ini:

"Setiap ruang pelayanan harus menyusun daftar kebutuhan obat dengan memperhatikan data konsumsi, data epidemiologi serta data jumlah stok yang ada. Daftar kebutuhan tersebut dikirim ke kepala instalasi farmasi, selanjutnya kepala instalasi farmasi merekap seluruh usulan ruangan-ruangan tersebut, setelah itu di usulkan kepada pengendali program yaitu direktur penunjang medic, sesudah itu direktur penunjang medic memasukan usulan tersebut kepada pengedali anggran, setalah hal-hal tersebut di lengkapi barulah direktur utama memberi laporan ke pusat, setelah keluar anggrannya maka di laporkan ke bagian pengadaan barang dan jasa untuk dibuka lelang pengadaan obat dapat dilihat pada SIRUP online.”(Sumber informasi I)

Makna hasil Penelitian Perencanaan obat yang dilakukan setiap ruangan dengan melaporkan kebutuhan ruangan kepada Kepala Instalasi Farmasi selanjutnya Instalasi Farmasi membuat laporan kebutuahan yang diteruskan ke Bagian logistik dan dilakukan pelaporan ke pada Direktur selanjuya Direktur melapor Kepada Pemerintah Pusat dan dilakukan Tender. Berikut ini gambar alur perencanaan obat:

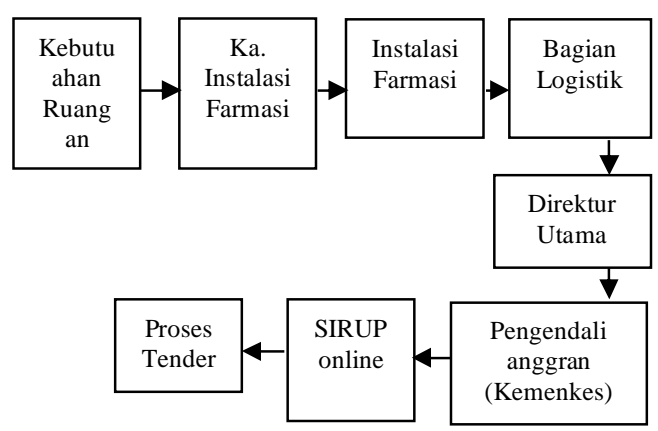

Gambar 1. Alur perencanaan obat

Hasil wawancara dengan sumber informasi tentang Metode dan analisis yang digunakan dalam proses perencanaan Rumah Sakit Dr M. Djamil Kota Padang.

Menggunakan metode konsumsi dan analisis ABC. Berikut ini adalah tabel analisis ABC:

Tabel 2. Analisis ABC Rumah Sakit Umum Dr. M. Djamil Kota Padang ${ }^{(6)}$

\begin{tabular}{|c|c|c|c|}
\hline Kelompok & Item & Jumlah Pemakaian & Persentase \\
\hline A & 124 & 566.214 & 70 \\
B & 176 & 104.106 & 20 \\
C & 707 & 52.240 & 10 \\
\hline Total & 1007 & 732.560 & 100 \\
\hline
\end{tabular}

Menurut Kepmenkes RI No. 1197/MENKES/SK/X/2004, perencanaan merupakan proses kegiatan dalam pemilihan jenis, jumlah, dan harga pembekalan farmasi yang sesuai dengan kebutuahan dan anggaran, untuk menghindari kekosongan obat dengan mengunakan metode yang dapat dipertanggung jawabkan dan dasar-dasar perencanaan yang telah ditentukan antara lain konsumsi, epidemiologi, kombinasi metode konsumsi dan epidemiologi disesuaikan dengan anggaran yang tersedia. Metode Konsumtif, yang didasarkan atas analisis data konsumtif/pemakaian pembekalan obat tahun sebelumnya dengan berbagai penyesuaian dan koreksi. Langkahlangkah perencanaan dengan mengunakan metode konsumsi. Analisis ABC merupakan pembagian konsumsi obat dan pengeluaran untuk perencanaan ${ }^{(7),(8),(9)}$. Metode ini cenderung pada profit oriented product karena berdasar pada dana yang dibutuhkan dari masing-masing obat. Inti dari análisis ABC adalah mengelompokan item obat kedalam tiga jenis klasifikasi berdasarkan volumen tahunan dalam jumlah uang. Kelompok analisis ABC yaitu:

1. Butir persedian kelompok A adalah persedian yang jumlah nilai uang pertahunnya tinggi (60-90\%), tetapi biasanya volumenya kecil. 
2. Butir persedian kelompok $B$ adalah persedian yang jumlah nilai uang per tahunnya sedang (20-30\%).

3. Butir persedian kelompok $\mathrm{C}$ adalah persedian yang jumlah nilai uang per tahunnya rendah (10-20\%), tetapi biasanya volumenya besar.

Berdasarkan hasil wawancara, dan teori yang ada peneliti maknai bahwa perencanaan obat sudah mendungkung di rumah sakit umum Dr. M. Djamil Kota Padang.

Dapat peneliti simpulkan bahwa rumah sakit menjalankan sistem perencanaan obat dalam menentukan perencanaan obat yang akan datang dengan baik.

\section{Pendistribuasian Obat di Instalasi Farmasi Rumah Sakit Umum Dr. M. Djamil Kota Padang}

Hasil wawancara dengan sumber informasi, pengadaan obat di Instalasi Farmasi Rumah Sakit Dr. M. Djamil sebagai berikut:

"Pendistribusian obat di rumah sakit mengunakan sistem desentralisasi, memiliki depo disetiap unit pelayanan angar mempermudah pasien dalam mengambil obat dilihat lansung dilapangan.”(Sumber Informasi I)

"Pendistribusian desentralisasi, ada depo disetiap ruang perawatan, alurnya dari gudang ke apotik lalu apotik yang menyuplai ke depo bila obat tidak instalasi farmasi mempunyai backup apotik kimia farma untuk memenuhi kebutuhan obat yang diperlukan.” (Sumber Informasi II)

"Petugas gudang farmasi memasukan obat ke apotik pada saat dilakukan pelaporan bahwa obat habis atau tidak ada, kalau obat itu diperlukan dalam keadaan darurat perawat akan lansung melakukan permintaan ke instalasi farmasi, kalau untuk pasien rawat jalan bila obat yang diminta tidak ada kami member laporan ke pada instlasi farmasi, dan menjelaskan kepada pasien atau keluarga pasien untuk mengambil obat yang dibutuhkan di kimiafarma." (Sumber Informasi VI)

Menurut Febriawati (2013), Desentralisasi pelayanan obat mempunyai cabang didekat unit perawatan/pelayanan sehingga penyimpanan dan pendistribusian kebutuhan obat untuk unit perawatan/ pelayanan tersebut baik untuk kebutuhan individu maupun kebutuhan dasar ruangan tidak lagi dilayani dari gudang farmasi ${ }^{(10)}$. Hasil wawancara penelitian pendistribusian obat peneliti maknai bahwa sistem desentralisasi dan bila obat tidak ada di apotik ataupun gudang farmasi maka instalasi farmasi meminta bantuan apotik kimia farma yang berada diluar rumah sakit sebagai pihak ekternal. Berikut ini gambar sistem desentralisasi pendistribusian obat:

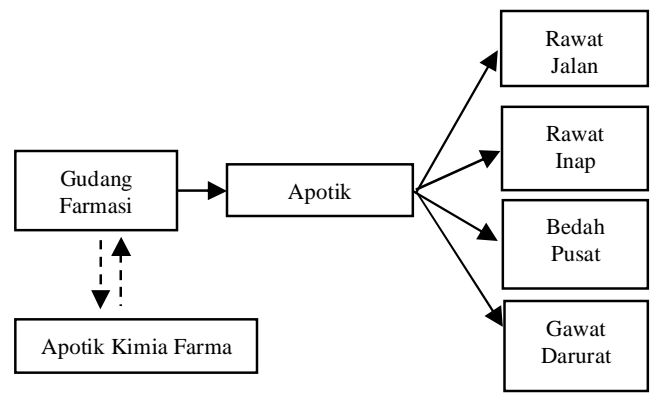

Gambar 2 Desentralisasi Pendistribusian Obat

Berdasarkan hasil wawancara penelitian dan teori yang ada peneliti maknai proses pendistribusian obat melibatkan pihak ekternal yang berada di luar rumah sakit yang mengakibatkan proses pendistribusian menjadi masalah pada penyaluran pada pasien karena rumah sakit tidak dapat memenuhi kebutuhan pasien dengan cepat dan memakan waktu yang relative lama peneliti asumsikan bahwa proses penyimpnan obat belum mendukung pengelolaan obat di Rumah Sakit Umum Dr. M. Djamil Kota Padang. Peneliti simpulkan bahwa pendistribusian obat di Instalasi Farmasi Rumah Sakit Umum Dr. M. Djamil Kota Padang belum berjalan dengan baik.

\section{PEMBAHASAN}

Pembahasan hasil observasi yang peneliti temukan dilapangan dan dicatat dalam bentuk ceklis peneliti lakukan penyederhanaan dalam bentuk kalimat dengan memilih dan memfokuskan pada objek observasi selanjutnya peneliti bandingkan dengan teori dan penelitian terdahulu untuk mendapatkan gambaran dan menjawab manajemen logistik obat di Instalasi Farmasi Rumah Sakit Umum Dr. M. Djamil Kota Padang apakah sudah baik atau belum baik. 
1. Sistem Pengeluaran Obat di Instalasi Farmasi Rumah Sakit Dr. M. Djamil Kota Padang mengunakan: FIFO dan FEFO

Hasil observasi barang yang baru datang dibelakang barang yang sebelumnya, peneliti amati bahwa ada petugas yang hanya meletakan barang tanpa milihat barang yang sebelumnya, ada juga obat yang baru datang diletakan didepan oleh petugas.

Menurut Quick, dkk (1997), First In First Out (FIFO) Sistem penataan obat atau perbekalan farmasi dengan meletakkan barang baru (datang terakhir) di belakang barang yang datang sebelumnya. First Expired First Out (FEFO) Sistem penataan obat atau perbekalan farmasi dengan meletakkan obat yang mempunyai tanggal kadaluarsa lebih dahulu di depan obat yang mempunyai tanggal kadaluarsa lebih akhir ${ }^{(11)}$. Dari hasil observasi dan teori yang ada peneliti simpulkan bahwa sistem penataan FIFO dan FEFO sangat baik di Instalasi Farmasi Rumah Sakit Dr. M. Djamil Kota Padang.

2. Sistem Penyimpanan di Instalasi Farmasi Rumah Sakit Dr. M. Djamil Kota Padang mengunakan: Semi Fluid Location

Hasil observasi berdasarkan yang peneliti lihat dan amati setiap barang atau obat yang ada disusun berdasarkan namanya, ditempat yang sama, dan barang yang khusus seperti obat narkotika diletakan ditempat yang berbeda. Menurut Quick,dkk (1997), Semi Fluid Location sistem ini merupakan kombinasi dari sistem kedua di atas. Sistem ini diibaratkan seperti hotel yang digunakan oleh tamu. Setiap barang selalu mendapatkan tempat yang sama. Barang yang khusus diberikan tempat tersendiri ${ }^{(11)}$. Dalam sistem ini, setiap item ditandai dengan penempatan barang yang cocok supaya mempermudah dalam mengambil stok. Saat menyediakan pesanan karyawan harus mengetahui di mana letak setiap item, untuk memudahkan dalam mengingat setiap item. Untuk barang yang slow moving perlu dilakukan pemilihan lokasi dan penataan ulang. Sistem ini tidak menghemat tempat seperti sistem fluid location. Adapun keistimewaan sistem ini adalah ketika mengambil stok selalu diperhatikan tempat yang sama. Tidak seperti sistem fixed location, dimana resiko tertukar barang yang relatif lebih kecil.

Dari hasil observasi dan teori yang ada peneliti simpulkan bahwa penyimpanan di Rumah Sakit Umum Dr. M. Djamil Kota Padang mengunakan Semi Fluid Location sesuai menurut Quick, dkk (1997), maka disimpulkan penyimpanan obat Rumah Sakit Umum Dr. M. Djamil Kota Padang sudah baik.

\section{KESIMPULAN}

Berdasarkan hasil penelitian serta pembahasan yang telah dilakukan dapat diambil kesimpulan proses Manajemen Logistik Perencanaan dan Pendistribusian Obat Pada Intalasi Farmasi di RSUP Dr M.Djamil Padang sebagai berikut: Perencanaan Obat di Instalasi Farmasi Rumah Sakit Umum Dr. M. Djamil Kota Padang sudah baik dan mampu mendukung dalam pelaksanaan Manajemen Logistik Obat di Instalasi Farmasi Rumah Sakit Umum Dr. M. Djamil Kota Padang. Kemudia, pendistribusian Obat di Instalasi Farmasi Rumah Sakit Umum Dr. M. Djamil Kota Padang belum baik dikarenakan sistem destralisasi dibantu oleh ekternal untuk penyaluran obat di Rumah Sakit Umum Dr. M. Djamil Kota Padang.

\section{DAFTAR PUSTAKA}

1. Suci Suciati WBA. Analisis Perencanaan Obat Berdasarkan ABC Indeks KKritis di Instalasi Farmasi. Manaj Pelayanan Kesehat. 2006;09:19-26.

2. Yasli DZ. Manajemen Logistik di Instalasi Farmasi Rumah Sakit Umum Dr. M. Djamil Kota Padang Tahun 2015. 2015.

3. Ayu G. Harian Padang Expres Duh, Sulitnya Mendapatkan Pelayanan BPJS [Internet]. 2015. Available from: http://www.koran.padek.co/read/detail/25299

4. Dinkes Prov. Sumbar. Profil Kesehatan Provinsi Sumatera Barat 2014. Padang: Dinkes Prov. Sumbar; 2015.

5. Efferin S. Metodologi Penelitian. Jakarta: Ghalia Indonesi; 2004.

6. RSUP Dr. M.Djamil. Laporan RSUP Dr. M.DJamil. Padang, Indonesia; 2019.

7. Kemenkes RI. Standar Pelayanan Farmasi di Rumah Sakit Nomor 1197/MENKES/SK/X/2004. Jakarta: Kemenkes RI; 2004.

8. Kemenkes RI. Permenkes Nomor 34 Tahun 2016 Tentang Perubahan Atas Peraturan Menteri Kesehatan Nomor 58 Tahun 2014 Tentang Standar Pelayanan Kefarmasian Di Rumah Sakit. Jakarta: Kemenkes RI; 2014.

9. Kemenkes RI. Peraturan Menteri Kesehatan. Nomor 63 Tahun 2014 tentang Pengadaan Obat Berdasarkan Katalog Elektronik (E-Catalogue). Jakarta: Kemenkes RI; 2014.

10. Febriawati H. Manajemen Logistik Farmasi Rumah Sakit. Yogyakarta: Gosyen Publishing; 2013.

11. Quick JD, Hume ML, Rankin JR, O’Connor R. Managing Drug Suplay, Revised and Expendet. Weth Hartford: Kumarin Press; 1997. 